\title{
Effects of serpentinite fertilizer on the chemical properties and enzyme activity of young spruce soils**
}

\author{
Ewa Błońska ${ }^{1 *}$, Kazimierz Januszek ${ }^{1}$, Stanisław Małek ${ }^{2}$, and Tomasz Wanic ${ }^{1}$ \\ ${ }^{1}$ Department of Forest Soils, ${ }^{2}$ Department of Forest Ecology and Reclamation, \\ Faculty of Forestry, University of Agriculture in Kraków, Al. 29-go Listopada 46, 31-425 Kraków, Poland
}

Received January 4, 2016; accepted September 30, 2016

\begin{abstract}
A b s t r a c t. The experimental plots used in the study were located in the middle forest zone (elevation: 900-950 $\mathrm{m}$ a.s.1.) on two nappes of the flysch Carpathians in southern Poland. The aim of this study was to assess the effects of serpentinite in combination with nitrogen, phosphorus, and potassium fertilizers on selected chemical properties of the soil and activity of dehydrogenase and urease in the studied soils. All fertilizer treatments significantly enriched the tested soils in magnesium. The use of serpentinite as a fertilizer reduced the molar ratio of exchangeable calcium to magnesium, which facilitated the uptake of magnesium by tree roots due to competition between calcium and magnesium. After one year of fertilization on the Wisła experimental plot, the $\mathrm{pH}$ of the Ofh horizon increased, while the $\mathrm{pH}$ of the mineral horizons significantly decreased. Enrichment of serpentinite with nitrogen, phosphorus, and potassium fertilizers stimulated the dehydrogenase activity in the studied organic horizon. The lack of a negative effect of the serpentinite fertilizer on enzyme activity in the spruce stand soil showed that the concentrations of the heavy metals added to the soil were not high enough to be toxic and indicated the feasibility of using this fertilizer in forestry.

K e y w o r d s: spruce stand soil, fertilizer use, chemical properties, dehydrogenase activity, urease activity
\end{abstract}

\section{INTRODUCTION}

In recent years in Europe, spruce mortality has been a serious problem in forestry and this key problem occurs on both sides of Poland southern border. The highest mortality rates have been recorded in the Silesian Beskid Range

\footnotetext{
*Corresponding author e-mail: eblonska@ar.krakow.pl

**This study was financed by the National Forest Holding of Poland as part of Project No. 3/08: 'Forest management measures improving growth, nutrition, and health conditions in forest regeneration areas and endangered stands in the Beskidy Mountains, with particular emphasis on soil revitalization using dolomites and new multi-component, long-acting fertilizers', 2008-2012.
}

and Żywiec Beskid Range (Błońska et al., 2015; Januszek et al., 2011; Małek et al., 2012); they were related to magnesium deficiency in the soil and tree needles (Januszek, 2006; Małek, 2010; Šrámek et al., 2010). Magnesium deficit symptoms have also been noted in other forested areas (Jandl et al., 2001; Landmann et al., 1997). The importance of $\mathrm{Mg}$ in crop production has been underestimated in the last decades (Cakman and Yazici, 2010; Gransee and Führs, 2013). Dolomite fertilization of spruce soils in the Höglwald in southern Bavaria increased significantly and permanently only the Ca concentration in needles, but not so much the concentration of $\mathrm{Mg}$, although the amounts of $\mathrm{Ca}$ and $\mathrm{Mg}$ in the dolomite were the same (Huber et al., 2006). The 'antagonism' between $\mathrm{Ca}$ and $\mathrm{Mg}$ explains the negative effect of liming on plant growth. The harmful effects of high doses of lime on the plant yield cause imbalance between $\mathrm{Ca}$ and $\mathrm{Mg}$ in the soil (Gorlach and Gorlach, 1983). The correct ratio of $\mathrm{Ca}: \mathrm{Mg}$ in the soil and in plants may be an important factor for optimal plant growth. Serpentinite rock is mainly composed of $\mathrm{Mg}$ silicate, but it also contains heavy metals, mainly nickel and chromium. Compared with carbonate rocks such as dolomite, serpentinite reacts more slowly. Serpentinite fertilization with $\mathrm{N}$, $\mathrm{P}$, and $\mathrm{K}$ fertilizer may improve the condition of dying spruce stands (Małek et al., 2011), as it enriches the soil and needles with $\mathrm{Mg}, \mathrm{P}, \mathrm{K}$, and $\mathrm{N}$; with an increase in organic matter mineralization and plant yield, it also affects the chemical and biological properties of the soil (Melero et al., 2006). The assessment of soil conditions is essential to monitor the stability of forest ecosystems.

(C) 2016 Institute of Agrophysics, Polish Academy of Sciences 
Soil chemical properties change slowly over time with drastic environmental changes, whereas biochemical properties such as enzyme activity react quickly to changes in the environment, as they are directly related to the number and activity of soil microorganisms (Trasar-Cepeda et al., 2000; Zhang et al., 2015). Studies have shown that soil enzyme activity decreases significantly with increasing contamination with heavy metals, and this is especially true of dehydrogenase and urease activity (Chen et al., 2005). In addition, enzyme activity is sensitive to soil changes due to tillage, use of cropping systems, and land use (Acosta-Martínez et al., 2007). The determination of soil enzyme activity can also provide insight into potential nutrient transformation (Tabatabai and Dick, 2002). Many researchers have studied the effects of chemicaltype fertilization on overall soil fertility by investigating the level of soil enzyme activity (Liu 2004; Gianfreda and Ruggiero, 2006; Nannipieri et al., 2012). Mijangos et al. (2006) and Ajwa et al. (1999) showed that biological parameters were sensitive to early changes in soil properties induced by different land management strategies and types of fertilization. The same pattern of sensitivity was not observed for conventional chemical parameters. Dehydrogenase activity is an indication of microbial activity in soil and has been used to assess the impact of management on soil quality, and the degree of recovery of degraded soils (Gil-Sotres et al., 2005). These researchers argue that urease activity should be used as an indicator of changes in soil quality due to fertilization.

The aim of this study was to assess the effect of serpentinite fertilization enriched with $\mathrm{N}, \mathrm{P}$, and $\mathrm{K}$ fertilizers on selected chemical properties of the soil and the activity of dehydrogenase and urease in the soil. Another goal was to evaluate the impact of heavy metals introduced with the fertilizer on soil properties and the feasibility of using serpentinite as a magnesium fertilizer. In the study, we have hypothesized that: 1) fertilization improves the chemical properties as well as the level of enzyme activity of the soil 2) heavy metals, especially nickel, introduced with the fertilizer, do not produce a negative impact on the level of enzyme activity.

\section{MATERIAL AND METHODS}

The study was conducted in southern Poland in the Ujsoły and Wisła Forest Districts (Coordinates: Wisła 49³8'12.92 N 1858'56.36 E; Ujsoły - 49²4'58.02 N $19^{\circ} 10^{\prime} 18.18$ E). Experimental plots were selected following an analysis of site conditions including geology, soil type, and forest stand characteristics. The plots were set up in two Carpathian areas:

- Magura Nappe region, on thin-bedded sandstone with some clayey-marly slate inclusions and a clayey wastemantle with meso/eutrophic soils, characterized by a high $\mathrm{Ca}$ to $\mathrm{Mg}$ ratio - also known as the Ujsoly Forest District;
- Silesian Nappe on Barania Góra Mountain, on lower Istebna layers, consisting of thick-bedded sandstone and conglomerate and a sandy-clayey waste-mantle with oligotrophic soils, characterized by Mg deficiency - also known as the Wisła Forest District.

Haplic Podzol soils formed of very stony, coarse sandy loam stratiform of very cobbly sandy loam with mor humus was noted on the experimental plots in Wisła. The Endoeutric Cambisol built of loam deposition on very cobbly clay loam and very cobbly silty-clay loam with the moder type of humus was noted on the experimental plots in Ujsoły.

The experimental plots were located in the middle forest zone among spruce stands in the 2nd age category (21-40 years). The experiment was carried out on $10 \times 10 \mathrm{~m}$ plots, with $5 \mathrm{~m}$ insulating strips between the plots. The plots were treated with six different types of fertilizer and each treatment was repeated three times. Serpentinite was added in the autumn of 2008, and the other fertilizers in the spring of 2009. The six fertilizer treatments used were as follows: (C) control plot - no fertilizer, (S) ground serpentinite (2000 kg ha-1 in the Ujsoły Forest District, $4000 \mathrm{~kg} \mathrm{ha}^{-1}$ in the Wisła Forest District), (SN) serpentinite + N (ammonium nitrate: $150 \mathrm{~kg} \mathrm{~N} \mathrm{ha}^{-1}$ ), (SP) ground serpentinite $+\mathrm{P}$ (400 kg of granulated triple superphosphate), (SNP) ground serpentinite + NP (ammonium nitrate ha ${ }^{-1}: 150 \mathrm{~kg} \mathrm{~N} \mathrm{ha}^{-1}$ and granulated triple superphosphate $\mathrm{ha}^{-1}: 80 \mathrm{~kg} \mathrm{P}^{-1}$ ), (SNPK) ground serpentinite + NP (formulated above) $+\mathrm{K}$ (potassium sulphate: $110 \mathrm{~kg} \mathrm{~K} \mathrm{ha}^{-1}$ ). The serpentinite used in the study contained the following macro- $(\%)$ and microelements $\left(\mathrm{mg} \mathrm{kg}^{-1}\right)$ : C: $1.67 ; \mathrm{N}: 0.001 ; \mathrm{S}: 0.011 ; \mathrm{Na}: 0.009$; K: 0.006; Ca: 0.39; Mg: 18.10; Fe: 5.77; Mn: 621.5; Zn: 38.4; Cu: 11.5; Cd: 1.96; Ni: 1,673.21; Pb: 1.25; Cr: 131.5 .

Samples for laboratory testing were collected from the organic horizon, the first mineral horizon down to $20 \mathrm{~cm}$ ( $\mathrm{AE}$ or $\mathrm{AB}$ ), and the second mineral horizon (from 20 to $35 \mathrm{~cm}$ - horizon B). Four subsamples were collected from each plot and were thoroughly mixed to give a composite soil sample. The samples were collected in August in 2009 and 2010. Enzyme activity was then determined for samples taken from the first two horizons. Dehydrogenase and urease activity was determined for samples collected in August 2009 and August 2010. Enzyme activity was determined by taking a naturally moist sample, sieving it through a sieve (Ø $2 \mathrm{~mm}$ ), and storing it at $4^{\circ} \mathrm{C}$ prior to analysis. Samples designated for the analysis of chemical properties were first dried at room temperature to an airdry condition, and were then sieved. The analysis of these samples included (Carter and Gregorich, 2006; Ostrowska et al., 1991):

- soil $\mathrm{pH}$ in $\mathrm{H}_{2} \mathrm{O}$ and $1 \mathrm{M} \mathrm{KCl}$ solution, determined potentiometrically;

- exchangeable aluminium $\left(\mathrm{H}_{\mathrm{Al}}\right)$ determined with the Sokołow method; 
- hydrolytic acidity (Y) determined using the Kappen method;

- total nitrogen and carbon content determined using a $\mathrm{LECO}$ analyser, which calculates the $\mathrm{C} / \mathrm{N}$ ratio;

- alkaline cation content in $1 \mathrm{M}$ ammonium acetate with calculation of effective cation exchange capacity $\left(\mathrm{T}_{\mathrm{e}}\right)$ and the degree of soil saturation with alkaline cations (V\%);

- available phosphorus with the Bray-Kurtz method;

- $\mathrm{Cd}, \mathrm{Cr}, \mathrm{Cu}, \mathrm{Ni}, \mathrm{Pb}$, and $\mathrm{Zn}$ content in $1 \mathrm{M} \mathrm{HCl}$ solution (ICP OES iCAP 6000 DUO, Thermo Fisher Scientific, Cambridge, UK);

- manual calculation of $(\mathrm{Ca}+\mathrm{Mg}+\mathrm{K}): \mathrm{Al}$ and $\mathrm{Ca}: \mathrm{Mg}$ ratios.

Dehydrogenase activity was determined according to the Casida procedure (Alef and Nannipieri, 1995) and expressed in mg of triphenyl formazan (TPF) on $100 \mathrm{~g}$ of soil released per $24 \mathrm{~h}$. The TTC method uses 3\% of triphenyltetrazolium chloride (TTC) as a substrate. The resulting formazan was extracted from the soil with ethyl alcohol and methanol (Alef and Nannipieri, 1995). Urease activity was determined using the Tabatabai and Bremner method (1972) with water solution as a substrate. The level of activity was determined by the amount of $\mathrm{NH}_{4}^{+}$that was released after $2 \mathrm{~h}$ at $37^{\circ} \mathrm{C}$ (Alef and Nannipieri, 1995). Each determination of the level of enzyme activity was repeated three times.

Statistical data analysis was performed using Statistica 10 software. In order to reduce the number of variables in the statistical dataset and visualize the multivariate dataset, principal component analysis (PCA) was used in the process. PCA was also used to interpret factors dependent on the dataset type. Chemical properties and enzyme activity levels were used as inputs in the PCA analysis. Differences between mean values were evaluated using the nonparametric Kruskal-Wallis test. The statistical significance of the results was verified at a significance level of $\alpha=0.05$.

\section{RESULTS}

The $\mathrm{pH}$ of organic horizons (Ofh and $\mathrm{Oh}$ ) was increased by the fertilizer treatments (S, SN, SP, SNPK, SNP) compared with the control sample (C) one and two years following the fertilization (Tables 1 and 2). The maximum difference of $0.82 \mathrm{pH}$ units in the mean $\mathrm{pH}$ in $\mathrm{H}_{2} \mathrm{O}$ was observed for the Oh horizon of soil in the Ujsoły plot between the SNP variants and control sample (C) treatments in 2009. In the B horizon of soils obtained from the Wisła plot, $\mathrm{pH}$ was lower in the fertilizer variants in relation to the control sample. The $\mathrm{pH}$ in $\mathrm{H}_{2} \mathrm{O}$ of the $\mathrm{B}$ horizon with the S, SP, SNP, and SNPK treatments applied to the Ujsoły plot was higher than that for the control sample. The concentrations of exchangeable aluminium in the Ofh horizon of fertilized soil sampled at the Wisła plot and in all the horizons of most fertilized soils sampled at the Ujsoły plot were lower compared with the $\mathrm{Al}^{3+}$ concentration noted for respective control soil samples (Tables 1 and 2). The largest decrease was noted for the $\mathrm{Al}^{3+}$ concentration in the $\mathrm{AB}$ horizon of the SP fertilized plots in the Ujsoly study area in $2009\left(7.57 \mathrm{cmol}(+) \mathrm{kg} \mathrm{soil}^{-1}\right)$ (Table 1). In the AE and B horizons of all fertilized soils from Wisła in 20092010, except those with $\mathrm{SN}$, the $\mathrm{Al}^{3+}$ concentrations were higher than those for the AE and $\mathrm{B}$ horizons of control soils (Tables 1 and 2). The Al concentration more than doubled in the B horizon with the $\mathrm{S}$ treatments in 2009 compared with that in the B horizon of the control soils (Table 1). In less than one year following the application of serpentinite, the $\mathrm{Al}$ concentration increased about $7.14 \mathrm{cmol}(+)$ $\mathrm{kg} \mathrm{soil}^{-1}$. The difference in the concentration of exchangeable $\mathrm{Al}$ in the $\mathrm{B}$ horizon between the $\mathrm{S}$ and $\mathrm{C}$ treatments in 2010 was smaller at $3.78 \mathrm{cmol}(+) \mathrm{kg} \mathrm{soil}^{-1}$. The tested soils were significantly enriched in $\mathrm{Mg}$ following the fertilization (Table 3); thus, the molar ratio of exchangeable $\mathrm{Ca}$ to $\mathrm{Mg}$ decreased. The mean value of the ratio of $\mathrm{Ca}, \mathrm{Mg}, \mathrm{K}$ : $\mathrm{Al}$ increased following the fertilization, particularly in the year 2010, when the highest concentrations of exchangeable Mg were noted (Table 3). In the organic horizon, both study plots exhibited significant differences in the ratio of $\mathrm{Ca}$ to $\mathrm{Mg}$ and values of $\mathrm{Ca}, \mathrm{Mg}, \mathrm{K}: \mathrm{Al}$ compared with the control sample (Table 3). In the case of the SN treatments, a tendency towards loss of exchangeable potassium from the soil was noted. Effective improvement in the supply of available phosphorus was observed as a result of the use of the superphosphate fertilizer. One year following the fertilization of the Ofh horizon, the phosphorus content increased in the fertilizer variants with $\mathrm{P}$ in relation to the control sample. A substantial share of the nickel released in the course of the weathering of serpentinite delivered to the soil is absorbed in the surface horizon, and only small amounts enter the full soil profile (Table 3). A significant difference $(<0.005)$ in soil properties $\left(\mathrm{pH}, \mathrm{Y}, \mathrm{Al}^{3+}, \mathrm{V}, \mathrm{N}, \mathrm{Ni}\right.$ content) was noted in the organic horizon compared with the control sample (Tables 1 and 2).

The activity of dehydrogenase in the organic horizon on the Wisła plot increased in 2009 compared with the control sample (C) in the case of the S and SN fertilization (Table 1). In 2010, the activity of dehydrogenase in the organic horizon increased in the case of all variants of fertilization in relation to the control sample - except for the SNP fertilization (Table 2). The activity of dehydrogenase in the $\mathrm{AE}$ horizon on the Wisła plots increased in 2009 in the case of the SP fertilization compared with the control sample (Table 1). The activity of dehydrogenase in the AE horizon increased in 2010 in the case of all the fertilization treatments compared with the control sample (Table 2). The activity of dehydrogenase in the organic horizon increased in 2009 on the Ujsoly plots compared with the control plot in the case of the SN, SNP, and SNPK fertilization (Table 1). The activity of dehydrogenase in the organic horizon decreased in 2010 in the case of all the plot fertilization treatments in relation to the control sample (Table 2). The 
T a b l e 1. Mean values of selected properties of the studied soils one year after fertilization

\begin{tabular}{|c|c|c|c|c|c|c|c|c|c|c|c|c|}
\hline \multirow{2}{*}{ Horizon } & \multirow{2}{*}{$\begin{array}{l}\text { Type } \\
\text { of } \\
\text { fertiliza- } \\
\text { tion }\end{array}$} & \multicolumn{2}{|c|}{$\mathrm{pH}$} & $\mathrm{Y}$ & $\mathrm{Al}^{3+}$ & \multirow{2}{*}{$\begin{array}{l}\mathrm{V}_{\mathrm{e}} \\
(\%)\end{array}$} & \multicolumn{2}{|c|}{ Total (\%) } & $\mathrm{Cr}$ & $\mathrm{Ni}$ & \multirow{2}{*}{ DH } & \multirow{2}{*}{ UR } \\
\hline & & $\mathrm{H}_{2} \mathrm{O}$ & $\mathrm{KCl}$ & \multicolumn{2}{|c|}{$\operatorname{cmol}(+) \mathrm{kg}^{-1}$} & & $\mathrm{C}$ & $\mathrm{N}$ & \multicolumn{2}{|c|}{$\left(\mathrm{mg} \mathrm{kg}^{-1}\right)$} & & \\
\hline \multicolumn{13}{|c|}{ Wisła } \\
\hline \multirow{6}{*}{ Ofh } & $\mathrm{C}$ & $3.50 \mathrm{a}$ & 2.71 & 90.48 & 21.35 & $10.46 \mathrm{a}$ & 29.50 & 1.30 & 0.52 & $2.38 \mathrm{a}$ & $40.0 \mathrm{ab}$ & 0.49 \\
\hline & $\mathrm{S}$ & $3.71 \mathrm{ab}$ & 2.81 & 95.12 & 20.60 & $19.31 \mathrm{ab}$ & 29.05 & 1.33 & 0.20 & $6.35 \mathrm{ab}$ & $62.6 \mathrm{~b}$ & 0.44 \\
\hline & $\mathrm{SN}$ & $3.74 b$ & 2.75 & 100.68 & 20.79 & $17.73 \mathrm{ab}$ & 31.68 & 1.41 & 0.16 & $5.63 \mathrm{ab}$ & 42.9ab & 0.43 \\
\hline & SP & $3.70 \mathrm{ab}$ & 2.83 & 95.42 & 18.20 & $25.52 \mathrm{~b}$ & 31.56 & 1.39 & 0.20 & $7.12 b$ & $30.4 \mathrm{ab}$ & 0.55 \\
\hline & SNP & $3.75 b$ & 2.82 & 89.42 & 17.83 & $24.89 b$ & 28.99 & 1.28 & 0.10 & $6.29 \mathrm{ab}$ & $33.9 \mathrm{ab}$ & 0.26 \\
\hline & SNPK & $3.55 \mathrm{ab}$ & 2.71 & 108.68 & 21.65 & $20.76 \mathrm{ab}$ & 32.88 & 1.40 & 0.18 & $7.60 \mathrm{~b}$ & $10.5 \mathrm{a}$ & 0.43 \\
\hline \multirow{6}{*}{$\mathrm{AE}$} & $\mathrm{C}$ & 3.66 & 2.71 & 16.06 & 6.24 & 4.11 & 3.57 & 0.17 & 1.29 & 1.06 & 23.9 & 0.19 \\
\hline & $\mathrm{S}$ & 3.50 & 2.79 & 22.59 & 8.66 & 4.56 & 4.02 & 0.20 & 0.77 & 0.28 & 17.6 & 0.17 \\
\hline & $\mathrm{SN}$ & 3.57 & 2.72 & 16.54 & 5.21 & 5.65 & 4.20 & 0.19 & 0.13 & 0.15 & 23.3 & 0.67 \\
\hline & SP & 3.62 & 2.82 & 18.68 & 9.86 & 3.99 & 3.97 & 0.18 & 0.66 & 0.54 & 28.5 & 0.34 \\
\hline & SNP & 3.50 & 2.79 & 19.66 & 7.51 & 7.80 & 4.12 & 0.18 & 0.48 & 0.23 & 20.7 & 0.15 \\
\hline & SNPK & 3.45 & 2.63 & 21.82 & 9.83 & 5.17 & 4.53 & 0.21 & 0.30 & 0.29 & 18.3 & 0.20 \\
\hline \multirow{6}{*}{ B } & $\mathrm{C}$ & 4.21 & 3.26 & 9.23 & 6.43 & 2.65 & n.d. & n.d. & 3.12 & 2.76 & n.d. & n.d. \\
\hline & $\mathrm{S}$ & 3.89 & 3.17 & 18.85 & 13.57 & 1.88 & n.d. & n.d. & 1.61 & 0.24 & n.d. & n.d. \\
\hline & SN & 3.88 & 3.05 & 11.79 & 6.11 & 3.45 & n.d. & n.d. & 1.29 & 0.71 & n.d. & n.d. \\
\hline & SP & 3.71 & 3.11 & 16.54 & 11.19 & 2.36 & n.d. & n.d. & 1.36 & 0.21 & n.d. & n.d. \\
\hline & SNP & 3.81 & 2.95 & 14.20 & 8.40 & 3.37 & n.d. & n.d. & 0.89 & 0.10 & n.d. & n.d. \\
\hline & SNPK & 3.64 & 3.18 & 16.53 & 11.30 & 3.19 & n.d. & n.d. & 1.31 & 0.73 & n.d. & n.d. \\
\hline \multicolumn{13}{|c|}{ Ujsoły } \\
\hline \multirow[t]{6}{*}{$\mathrm{Oh}$} & $\mathrm{C}$ & $4.35 \mathrm{a}$ & $3.41 \mathrm{a}$ & $58.44 b$ & $11.60 \mathrm{~b}$ & $45.99 \mathrm{a}$ & 22.65 & $1.01 \mathrm{~b}$ & 2.12 & $6.38 \mathrm{a}$ & $111.7 \mathrm{a}$ & 0.95 \\
\hline & $\mathrm{S}$ & $5.12 \mathrm{c}$ & 3.91abc & $29.00 \mathrm{a}$ & $4.01 \mathrm{a}$ & $75.98 \mathrm{bc}$ & 12.34 & $0.62 \mathrm{a}$ & 1.60 & $9.44 \mathrm{ab}$ & $99.8 \mathrm{a}$ & 0.71 \\
\hline & $\mathrm{SN}$ & $4.53 \mathrm{ab}$ & $3.69 \mathrm{ab}$ & 46.76ab & $9.57 \mathrm{~b}$ & $58.69 \mathrm{ab}$ & 18.69 & $0.94 \mathrm{ab}$ & 1.30 & $7.24 \mathrm{a}$ & $146.8 \mathrm{ab}$ & 0.59 \\
\hline & SP & $5.07 \mathrm{c}$ & $4.27 c$ & $31.16 \mathrm{a}$ & $2.94 \mathrm{a}$ & $85.39 \mathrm{c}$ & 15.45 & $0.74 \mathrm{ab}$ & 2.07 & $9.26 \mathrm{ab}$ & $84.5 \mathrm{a}$ & 0.76 \\
\hline & SNP & $5.17 \mathrm{c}$ & $4.25 b c$ & $27.84 \mathrm{a}$ & $3.90 \mathrm{a}$ & $78.54 \mathrm{c}$ & 14.92 & $0.68 \mathrm{ab}$ & 2.97 & $13.66 \mathrm{bc}$ & $132.0 \mathrm{ab}$ & 0.62 \\
\hline & SNPK & $4.96 b c$ & $4.03 \mathrm{bc}$ & $42.20 \mathrm{ab}$ & $4.48 \mathrm{a}$ & $78.13 \mathrm{c}$ & 20.01 & $0.92 \mathrm{ab}$ & 2.02 & $16.35 \mathrm{c}$ & $177.7 \mathrm{~b}$ & 0.73 \\
\hline
\end{tabular}


T a b l e 1. Continuation

\begin{tabular}{|c|c|c|c|c|c|c|c|c|c|c|c|c|}
\hline \multirow{2}{*}{ Horizon } & \multirow{2}{*}{$\begin{array}{l}\text { Type } \\
\text { of } \\
\text { fertiliza- } \\
\text { tion }\end{array}$} & \multicolumn{2}{|c|}{$\mathrm{pH}$} & $\mathrm{Y}$ & $\mathrm{Al}^{3+}$ & \multirow{2}{*}{$\begin{array}{c}\mathrm{V}_{\mathrm{e}} \\
(\%)\end{array}$} & \multicolumn{2}{|c|}{ Total (\%) } & $\mathrm{Cr}$ & $\mathrm{Ni}$ & \multirow{2}{*}{$\mathrm{DH}$} & \multirow{2}{*}{ UR } \\
\hline & & $\mathrm{H}_{2} \mathrm{O}$ & $\mathrm{KCl}$ & \multicolumn{2}{|c|}{$\operatorname{cmol}(+) \mathrm{kg}^{-1}$} & & $\mathrm{C}$ & $\mathrm{N}$ & \multicolumn{2}{|c|}{$\left(\mathrm{mg} \mathrm{kg}^{-1}\right)$} & & \\
\hline \multirow{6}{*}{$\mathrm{AB}$} & $\mathrm{C}$ & $4.46 \mathrm{ab}$ & 3.46 & $25.86 \mathrm{ab}$ & 12.79 & 22.67 & 5.67 & 0.35 & 3.43 & 5.42 & 43.5 & 0.42 \\
\hline & $\mathrm{S}$ & $4.75 \mathrm{ab}$ & 3.64 & $18.50 \mathrm{ab}$ & 8.27 & 37.82 & 5.06 & 0.32 & 2.66 & 4.91 & 44.1 & 0.64 \\
\hline & SN & $4.30 \mathrm{a}$ & 3.50 & $28.09 \mathrm{ab}$ & 11.90 & 25.16 & 6.59 & 0.43 & 2.27 & 4.17 & 33.2 & 0.48 \\
\hline & SP & $4.91 \mathrm{~b}$ & 3.88 & $16.02 \mathrm{a}$ & 5.22 & 57.59 & 4.99 & 0.31 & 2.10 & 4.38 & 44.1 & 0.59 \\
\hline & SNP & $4.83 \mathrm{ab}$ & 3.90 & $16.47 \mathrm{a}$ & 5.23 & 58.14 & 5.18 & 0.31 & 2.99 & 5.55 & 44.7 & 0.50 \\
\hline & SNPK & $4.45 \mathrm{ab}$ & 3.59 & $32.57 b$ & 8.01 & 43.93 & 4.99 & 0.33 & 1.70 & 3.12 & 42.6 & 0.43 \\
\hline \multirow{6}{*}{ B } & $\mathrm{C}$ & 4.72 & 3.67 & 14.80 & 11.61 & 14.05 & n.d. & n.d. & 4.12 & 4.32 & n.d. & n.d. \\
\hline & $\mathrm{S}$ & 5.04 & 3.81 & 10.14 & 6.92 & 32.86 & n.d. & n.d. & 3.47 & 3.70 & n.d. & n.d. \\
\hline & $\mathrm{SN}$ & 4.65 & 3.69 & 13.99 & 10.85 & 13.68 & n.d. & n.d. & 3.30 & 3.37 & n.d. & n.d. \\
\hline & SP & 5.16 & 3.84 & 9.89 & 5.64 & 44.17 & n.d. & n.d. & 2.57 & 3.18 & n.d. & n.d. \\
\hline & SNP & 4.94 & 3.78 & 11.73 & 7.25 & 31.64 & n.d. & n.d. & 3.28 & 3.26 & n.d. & n.d. \\
\hline & SNPK & 5.42 & 4.37 & 12.76 & 9.90 & 20.45 & n.d. & n.d. & 2.23 & 2.40 & n.d. & n.d. \\
\hline
\end{tabular}

$\mathrm{C}$ - control plot - no fertilizer used, $\mathrm{S}-$ ground serpentinite, $\mathrm{SN}-$ serpentinite + nitrogen, $\mathrm{SP}-$ ground serpentinite $+\mathrm{P}, \mathrm{SNP}-$ ground serpentinite $+\mathrm{NP}, \mathrm{SNPK}-$ ground serpentinite $+\mathrm{NP}+\mathrm{K}, \mathrm{Y}-$ hydrolytic acidity, $\mathrm{Al}^{3+}-$ exchangeable aluminum, $\mathrm{V}-$ saturation of base cations, DH - dehydrogenase activity $\left(\mu \mathrm{M}\right.$ TPF kg $\left.{ }^{-1} h^{-1}\right), \mathrm{UR}$ - urease activity $\left(\mathrm{mM} \mathrm{N}-\mathrm{NH}_{4} \mathrm{~kg}^{-1} \mathrm{~h}^{-1}\right)$, different lower case letters in the upper index of mean values indicate significant differences.

activity of dehydrogenase in the $\mathrm{AB}$ horizon decreased in 2009 on the Ujsoly plots compared with the control sample in the case of the SN and SNPK fertilization (Table 1). The activity of dehydrogenase in the $\mathrm{AB}$ horizon increased in 2010 in the case of all the fertilization treatments in comparison with the control sample. The largest increase was observed in the case of the SNP fertilization (Table 2).

Urease activity in the Ofh horizon decreased in 2009 on the Wisła plots compared with the control plot in the case of all the fertilization treatments except the SP fertilization (Table 1). In 2010, urease activity did not increase in the organic horizon for any variant of fertilization. In 2009, urease activity decreased in the AE horizon on the Wisła plots, in comparison with the control sample, in the case of the the $\mathrm{S}$ and SNP fertilization treatments, and increased for the SN, SP, and SNPK fertilization treatments (Table 1). In 2010, urease activity in the AE horizon increased only for the SNPK variant of fertilization. In 2009, urease activity in the Oh horizon on the Ujsoły plots decreased, compared with the control plot, for all of the fertilization treatments employed (Table 1). In 2009 and 2010, urease activity in the $\mathrm{AB}$ horizon on the Ujsoly plots increased, compared with the control sample, in the case of all the fertilization treatments (Tables 1 and 2). Significant differences were noted in the organic horizon on the Wisła plot as well as in the organic horizon and $\mathrm{AB}$ horizon on the Ujsoły plot in terms of dehydrogenase activity (Tables 1 and 2).

The effects of fertilization on the tested surfaces are presented via principal component analysis (PCA) (Figs 1 and 2). The uniqueness of the plots analysed in the experiment in Wisła and Ujsoły in terms of chemical properties was confirmed by the analysis. The soil in the Ujsoły study area is characterized by a higher $\mathrm{pH}$, abundance of alkaline cations, a broad range of $\mathrm{Ca}: \mathrm{Mg}$ ratios, and a smaller supply of organic matter. The control plot results, compared with the fertilized plots, confirm the effects of the fertilizer use. The variants with the phosphorus fertilization (SP, SNP, SNPK) resulted in a noticeable increase in the content of magnesium and phosphorus in the organic horizon in the first year following the fertilization. The increase in dehydrogenase and urease activity was readily observable for the plots in the Ujsoly area and was also visible in the case of all the fertilization treatments used. A strong correlation between dehydrogenase activity and $\mathrm{pH}$ as well as exchangeable calcium content (in particular) was detected (Figs 1 and 2). A positive correlation between dehydrogenase activity and nickel content in the organic horizon of fertilized soils was also noted (Table 4). 
T a b l e 2. Mean values of selected properties of the studied soils two years after fertilization

\begin{tabular}{|c|c|c|c|c|c|c|c|c|c|c|c|c|}
\hline \multirow{2}{*}{ Horizon } & \multirow{2}{*}{$\begin{array}{l}\text { Type } \\
\text { of } \\
\text { fertiliza- } \\
\text { tion }\end{array}$} & \multicolumn{2}{|c|}{$\mathrm{pH}$} & Y & & \multirow{2}{*}{$\begin{array}{c}\mathrm{V}_{\mathrm{e}} \\
(\%)\end{array}$} & \multicolumn{2}{|c|}{ Total (\%) } & $\mathrm{Cr}$ & $\mathrm{Ni}$ & \multirow{2}{*}{$\mathrm{DH}$} & \multirow{2}{*}{ UR } \\
\hline & & $\mathrm{H}_{2} \mathrm{O}$ & $\mathrm{KCl}$ & $\mathrm{cm}$ & +) $\cdot \mathrm{kg}^{-1}$ & & $\mathrm{C}$ & $\mathrm{N}$ & \multicolumn{2}{|c|}{$\left(\mathrm{mg} \mathrm{kg}^{-1}\right)$} & & \\
\hline \multicolumn{13}{|c|}{ Wisła } \\
\hline \multirow{6}{*}{ Ofh } & $\mathrm{C}$ & $3.60 \mathrm{a}$ & $2.83 a$ & 88.59 & $15.68 \mathrm{~b}$ & $22.83 a$ & 32.67 & 1.40 & $1.00 \mathrm{~b}$ & $3.93 a$ & $72.3 \mathrm{a}$ & $0.44 b$ \\
\hline & $\mathrm{S}$ & $3.97 \mathrm{~b}$ & $3.07 \mathrm{~b}$ & 80.61 & $13.67 \mathrm{ab}$ & $41.54 b$ & 32.41 & 1.38 & $0.95 \mathrm{ab}$ & $18.43 b$ & $113.4 b$ & $0.37 \mathrm{ab}$ \\
\hline & SN & $4.08 \mathrm{~b}$ & $3.13 b$ & 77.72 & $10.17 \mathrm{a}$ & $51.93 b$ & 32.96 & 1.32 & $0.82 \mathrm{ab}$ & $21.88 \mathrm{~b}$ & $85.23 \mathrm{ab}$ & $0.44 b$ \\
\hline & SP & $3.99 \mathrm{~b}$ & $3.08 \mathrm{~b}$ & 78.38 & $12.74 \mathrm{ab}$ & $43.83 b$ & 32.55 & 1.36 & $0.68 \mathrm{ab}$ & $18.53 b$ & $107.4 b$ & $0.36 \mathrm{ab}$ \\
\hline & SNP & $4.12 b$ & $3.18 b$ & 77.05 & $9.87 \mathrm{a}$ & $55.24 b$ & 35.84 & 1.43 & $0.79 \mathrm{ab}$ & $19.22 b$ & $64.3 \mathrm{a}$ & $0.36 \mathrm{ab}$ \\
\hline & SNPK & $3.97 \mathrm{~b}$ & $3.06 \mathrm{~b}$ & 86.12 & $11.50 \mathrm{ab}$ & $49.11 \mathrm{~b}$ & 35.11 & 1.44 & $0.41 \mathrm{a}$ & $17.68 \mathrm{~b}$ & $79.3 \mathrm{a}$ & $0.27 \mathrm{a}$ \\
\hline \multirow{6}{*}{$\mathrm{AE}$} & $\mathrm{C}$ & 4.00 & 3.09 & 12.15 & 5.95 & 5.07 & $2.23 \mathrm{a}$ & $0.11 \mathrm{a}$ & 6.15 & 5.48 & 15.7 & 0.15 \\
\hline & $\mathrm{S}$ & 3.85 & 3.00 & 17.76 & 10.85 & 6.82 & $3.69 \mathrm{ab}$ & $0.16 \mathrm{ab}$ & 4.50 & 3.63 & 16.7 & 0.13 \\
\hline & SN & 3.85 & 3.02 & 14.36 & 5.61 & 7.43 & $4.28 b$ & $0.19 \mathrm{ab}$ & 8.08 & 6.56 & 16.4 & 0.12 \\
\hline & SP & 4.27 & 3.28 & 13.41 & 7.10 & 5.82 & $3.02 \mathrm{ab}$ & $0.14 \mathrm{ab}$ & 19.75 & 15.88 & 16.0 & 0.13 \\
\hline & SNP & 3.79 & 2.92 & 17.83 & 7.49 & 7.97 & $4.21 b$ & $0.20 \mathrm{~b}$ & 1.29 & 1.58 & 21.1 & 0.14 \\
\hline & SNPK & 3.79 & 2.90 & 17.98 & 11.13 & 4.31 & $3.92 \mathrm{ab}$ & $0.21 b$ & 3.82 & 3.83 & 19.8 & 0.17 \\
\hline \multirow{6}{*}{ B } & $\mathrm{C}$ & 4.06 & 3.22 & 12.55 & 7.77 & 3.27 & n.d. & n.d. & 4.79 & 4.05 & n.d. & n.d. \\
\hline & $\mathrm{S}$ & 3.97 & 3.11 & 16.02 & 11.65 & 4.14 & n.d. & n.d. & 3.72 & 2.85 & n.d. & n.d. \\
\hline & SN & 4.01 & 3.21 & 10.09 & 5.75 & 4.55 & n.d. & n.d. & 3.00 & 3.00 & n.d. & n.d. \\
\hline & SP & 4.08 & 3.19 & 16.95 & 12.12 & 2.52 & n.d. & n.d. & 2.94 & 2.42 & n.d. & n.d. \\
\hline & SNP & 4.01 & 3.13 & 11.37 & 9.41 & 3.65 & n.d. & n.d. & 1.44 & 1.37 & n.d. & n.d. \\
\hline & SNPK & 3.96 & 3.12 & 13.25 & 13.53 & 2.53 & n.d. & n.d. & 1.57 & 1.30 & n.d. & n.d. \\
\hline
\end{tabular}

Ujsoły

\begin{tabular}{|c|c|c|c|c|c|c|c|c|c|c|c|c|}
\hline \multirow[t]{6}{*}{$\mathrm{Oh}$} & $\mathrm{C}$ & $4.35 \mathrm{a}$ & $3.53 \mathrm{a}$ & $71.24 \mathrm{c}$ & $5.18 \mathrm{~b}$ & $74.47 \mathrm{a}$ & $32.04 b$ & $1.33 \mathrm{~b}$ & 1.74 & $5.11 \mathrm{a}$ & $241.4 b$ & $0.53 \mathrm{a}$ \\
\hline & $\mathrm{S}$ & $5.00 \mathrm{~b}$ & $4.24 b$ & $42.50 \mathrm{ab}$ & $2.29 \mathrm{ab}$ & $86.52 \mathrm{ab}$ & $23.66 \mathrm{a}$ & $0.94 \mathrm{a}$ & 3.41 & $23.50 \mathrm{~b}$ & $190.5 \mathrm{ab}$ & $0.77 \mathrm{ab}$ \\
\hline & SN & $4.81 \mathrm{ab}$ & $4.07 \mathrm{ab}$ & $51.44 b$ & $1.44 \mathrm{a}$ & $86.28 \mathrm{ab}$ & $28.48 \mathrm{ab}$ & $1.16 \mathrm{~b}$ & 1.83 & $29.48 b$ & $146.8 \mathrm{a}$ & $0.61 \mathrm{ab}$ \\
\hline & SP & $5.16 \mathrm{~b}$ & $4.44 b$ & $34.58 \mathrm{a}$ & $1.40 \mathrm{a}$ & $92.76 b$ & $26.16 \mathrm{a}$ & $1.01 \mathrm{a}$ & 2.37 & $26.40 \mathrm{~b}$ & $214.3 \mathrm{ab}$ & $0.89 b$ \\
\hline & SNP & $4.97 \mathrm{~b}$ & $4.18 \mathrm{~b}$ & $46.57 \mathrm{ab}$ & $2.92 \mathrm{ab}$ & $80.13 \mathrm{ab}$ & $23.96 \mathrm{a}$ & $0.97 \mathrm{a}$ & 2.67 & $24.79 b$ & $183.5 \mathrm{ab}$ & $0.71 \mathrm{ab}$ \\
\hline & SNPK & $4.96 \mathrm{~b}$ & $4.14 b$ & $44.53 \mathrm{ab}$ & $3.50 \mathrm{ab}$ & $82.06 \mathrm{ab}$ & $25.73 a$ & $0.99 \mathrm{a}$ & 1.94 & $22.83 b$ & $216.9 \mathrm{ab}$ & $0.67 \mathrm{ab}$ \\
\hline
\end{tabular}

Explanation as in Table 1. 
T a b l e 2. Continuation

\begin{tabular}{|c|c|c|c|c|c|c|c|c|c|c|c|c|}
\hline \multirow{3}{*}{ Horizon } & \multirow{2}{*}{$\begin{array}{l}\text { Type } \\
\text { of } \\
\text { fertiliza- } \\
\text { tion }\end{array}$} & \multicolumn{2}{|c|}{$\mathrm{pH}$} & $\mathrm{Y}$ & $\mathrm{Al}^{3+}$ & \multirow{2}{*}{$\begin{array}{c}\mathrm{V}_{\mathrm{e}} \\
(\%)\end{array}$} & \multicolumn{2}{|c|}{ Total $(\%)$} & $\mathrm{Cr}$ & $\mathrm{Ni}$ & \multirow[b]{2}{*}{ DH } & \multirow[b]{2}{*}{ UR } \\
\hline & & $\mathrm{H}_{2} \mathrm{O}$ & $\mathrm{KCl}$ & \multicolumn{2}{|c|}{$\operatorname{cmol}(+) \mathrm{kg}^{-1}$} & & $\mathrm{C}$ & $\mathrm{N}$ & \multicolumn{2}{|c|}{$\left(\mathrm{mg} \mathrm{kg}^{-1}\right)$} & & \\
\hline & $\mathrm{C}$ & $4.47 \mathrm{a}$ & $3.49 a$ & $26.80 \mathrm{c}$ & $10.71 \mathrm{~b}$ & $26.48 \mathrm{a}$ & 6.84 & 0.40 & 2.50 & $2.36 \mathrm{a}$ & $43.7 \mathrm{a}$ & $0.17 \mathrm{a}$ \\
\hline \multirow{5}{*}{$\mathrm{AB}$} & S & $4.85 \mathrm{bc}$ & $3.75 \mathrm{ab}$ & $19.15 \mathrm{ab}$ & $5.10 \mathrm{a}$ & $53.80 \mathrm{ab}$ & 5.98 & 0.37 & 2.10 & $15.54 \mathrm{~b}$ & $62.6 \mathrm{ab}$ & $0.35 b$ \\
\hline & SN & $4.65 \mathrm{ab}$ & $3.62 \mathrm{a}$ & $21.43 \mathrm{abc}$ & 7.70ab & $45.79 \mathrm{ab}$ & 6.84 & 0.41 & 2.83 & $5.33 \mathrm{ab}$ & $44.8 \mathrm{a}$ & $0.24 a b$ \\
\hline & SP & $5.08 \mathrm{c}$ & $3.89 b$ & $15.17 \mathrm{a}$ & $2.89 \mathrm{a}$ & $74.38 \mathrm{~b}$ & 5.98 & 0.36 & 2.39 & $5.34 \mathrm{ab}$ & $63.7 \mathrm{ab}$ & $0.33 \mathrm{ab}$ \\
\hline & SNP & 4.73abc & $3.61 \mathrm{a}$ & $22.46 b c$ & $4.44 \mathrm{a}$ & $64.70 \mathrm{~b}$ & 7.29 & 0.43 & 3.00 & $4.70 \mathrm{ab}$ & $74.0 \mathrm{~b}$ & $0.26 \mathrm{ab}$ \\
\hline & SNPK & $4.67 \mathrm{ab}$ & $3.61 \mathrm{a}$ & $23.24 b c$ & $6.86 \mathrm{ab}$ & $45.14 \mathrm{ab}$ & 6.87 & 0.40 & 2.14 & $2.50 \mathrm{a}$ & $51.9 \mathrm{ab}$ & $0.18 \mathrm{a}$ \\
\hline \multirow{6}{*}{ B } & $\mathrm{C}$ & 4.88 & 3.75 & 15.5 & 0.43 & 22.00 & n.d. & n.d. & 2.67 & 1.27 & n.d. & n.d. \\
\hline & S & 5.21 & 3.87 & 11.89 & 0.10 & 43.15 & n.d. & n.d. & 3.75 & 3.74 & n.d. & n.d. \\
\hline & SN & 4.89 & 3.76 & 4.62 & 0.16 & 20.97 & n.d. & n.d. & 3.00 & 3.00 & n.d. & n.d. \\
\hline & SP & 5.03 & 3.82 & 12.02 & 0.30 & 31.76 & n.d. & n.d. & 3.53 & 2.68 & n.d. & n.d. \\
\hline & SNP & 4.81 & 3.74 & 14.74 & 0.13 & 16.40 & n.d. & n.d. & 3.47 & 2.62 & n.d. & n.d. \\
\hline & SNPK & 4.72 & 3.76 & 14.23 & 0.07 & 19.97 & n.d. & n.d. & 2.80 & 0.98 & n.d. & n.d. \\
\hline
\end{tabular}

PCA analysis performed on the basis of data acquired via experimental means over a period of two years after the fertilization suggests a stronger effect of the fertilization on the studied soil properties. This was confirmed by a clear distinction between the fertilization treatment data compared with data for the control plot. Soil samples obtained from the organic horizon two years following the fertilization differ mainly in the content of magnesium, nickel, and to a lesser degree phosphorus. The effect on $\mathrm{pH}$ and increases in the concentration of calcium as well as increases in the level of activity of dehydrogenase and urease are more strongly reflected in the Ujsoły plots (Fig. 1).

\section{DISCUSSION}

It seems that the selection of serpentinite to fertilize the studied soils improves their conditions. Higher concentrations of magnesium as well as a larger percentage of magnesium in the sorption complex were detected for each of the fertilizer treatments, compared with the control plot. The selected dose for serpentinite $\left(2000 \mathrm{~kg} \mathrm{ha}^{-1}\right)$ proved to be correct in the case of the Ujsoły plot. No adverse effects were noted for the fertilized soils of Ujsoly. A negative effect was noted following the application of a much larger dose on the Wisła plot (4 $\left.000 \mathrm{~kg} \mathrm{ha}^{-1}\right)$ : acidifying fertilizers (potassium sulphate: $226 \mathrm{~kg} \mathrm{ha}^{-1}$ ) and ammonium nitrate $\left(440 \mathrm{~kg} \mathrm{ha}^{-1}\right)$. The soil $\mathrm{pH}$ increased in all soil horizons on the Ujsoly plot compared with the control plot in the case of all the fertilization treatments used. The highest $\mathrm{pH}$ was observed in soil in the case of the S and SP fertilization treatments. A decrease in $\mathrm{pH}$ and an increase in the concentration of exchangeable aluminium were noted in the $\mathrm{AE}$ and $\mathrm{B}$ horizons following the fertilization on the Wisła plot. The maximum decrease in $\mathrm{pH}$ in $\mathrm{H}_{2} \mathrm{O}$ recorded in the B horizon in $2009(0.57 \mathrm{pH}$ units from a pH of 4.21 for the control variant to a $\mathrm{pH}$ of 3.64 for SNPK) corresponds to the 3.7 times larger concentration of the hydrogen ion in one litre of solution in the B horizon of the SNPK variant compared with the control variant. In the AE horizon, this difference was less pronounced $(0.21$ units, from $\mathrm{pH}=$ 3.66 to 3.45 ) and corresponded only to the 1.6 times larger concentration of the hydrogen ion in one litre of solution in the AE horizon of SNPK compared with the soil in the $\mathrm{AE}$ horizon of the control sample used. The decrease in $\mathrm{pH}$ and the increase in the concentration of aluminium in the upper mineral horizons (AE and B) in 2009 and 2010 were the result of illuviation by rainwater-displaced acid cations from the sorption complex, hydrogen, and aluminium by magnesium, potassium, and ammonium released from the fertilizers introduced. The acidity of the upper mineral horizons induced by the use of dolomite was previously described in the literature (Kreutzer, 1995; Lundström et al., 2003), but it was not described for the use of a silicate fertilizer rich in alkaline cations. Therefore, lower doses of serpentinite should be used, especially when the serpentinite 
T a b l e 3. Mean trace element content and molar ratios for the studied soils one year and two years after fertilization

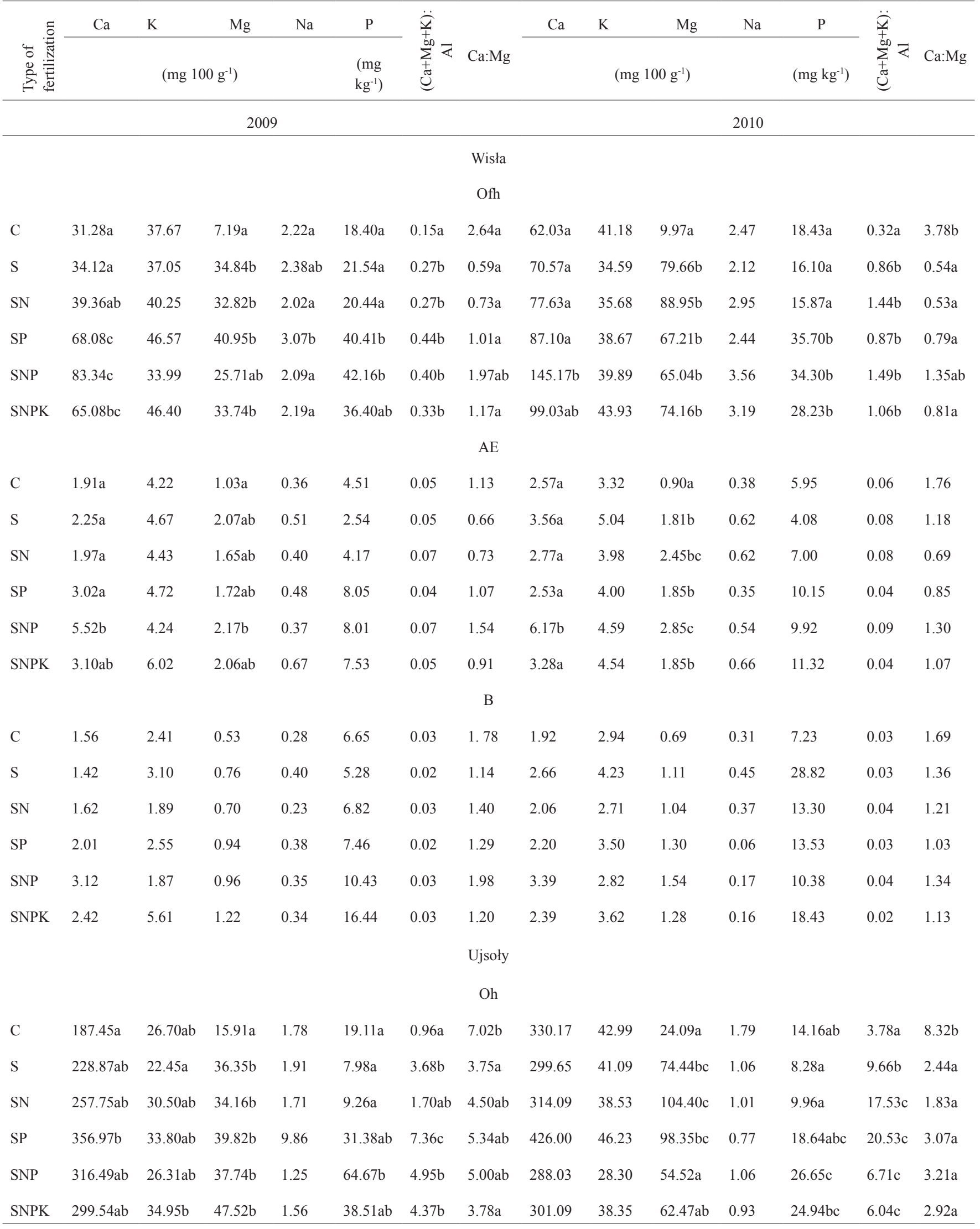


T a b l e 3. Continuation

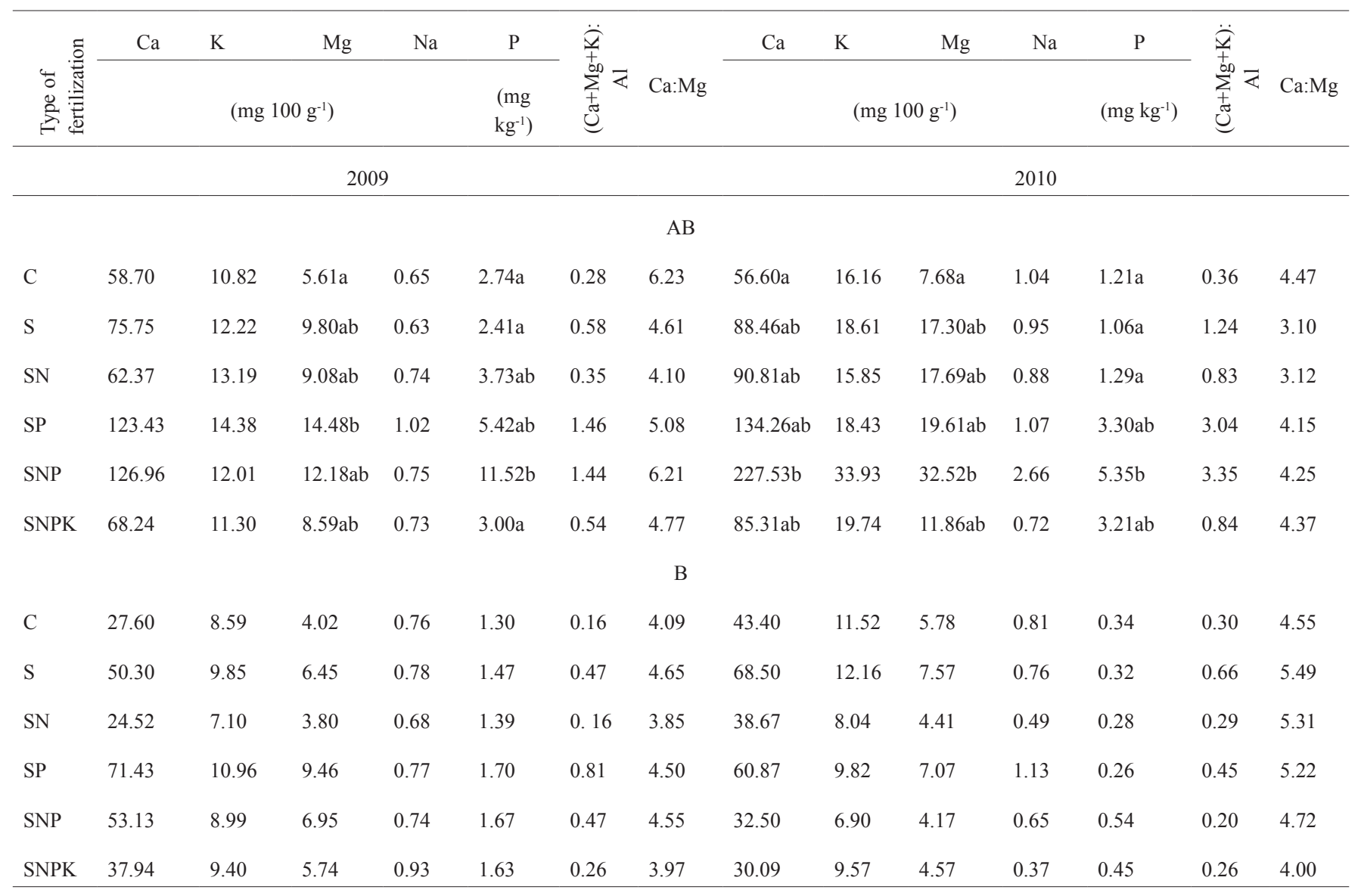

is applied in a mixture with fertilizers causing acidification. Fertilization with serpentinite in combination with nitrogen, phosphorus, and potassium affected the activity of enzymes such as dehydrogenase and urease. In the case of dehydrogenase activity in the $\mathrm{O}$ horizon of soils from the Wisła and Ujsoły plots, a marked increase was observed two years after the fertilization. The highest increase in soil dehydrogenase activity was noted after the serpentinite fertilization on the Wisła plots and after the application of the SNPK fertilizer on the Ujsoły plots. The increase in dehydrogenase activity may be due to an increase in the number of microorganisms and microbial activity. According to Xiaoguang et al. (2011), an increase in the level of soil enzyme activity in fertilizer-treated soils may be the consequence of both microbial growth and stimulation of microbial activity by enhanced resource availability, as well as due to changes in the makeup of the microbial community. While chemical $\mathrm{N}$ fertilizers inhibited soil enzyme activity, $\mathrm{P}$ and $\mathrm{K}$ fertilizers enhanced it (Yang et al., 2008; Yao et al., 2009). The research results obtained in this study confirmed the above findings. Fertilization in the SN variant poorly stimulated dehydrogenase activity compared with the variant with $\mathrm{P}$ and $\mathrm{K}$.
Soil enzymes are involved in biochemical processes and are closely linked with the circulation of nutrients, energy conversion, and environmental quality. The observed change in enzyme activity was caused by the use of the fertilizer, but this was not the only major factor. Fertilization directly affects the $\mathrm{pH}$ of the soil, with which dehydrogenase and urease activity is closely correlated. The increase in $\mathrm{pH}$ in the surface horizon is a result of fertilization. This affects the recovery of microbial activity and, consequently, leads to an increase in the activity of urease and dehydrogenase - mainly in the O horizon. Dehydrogenase and urease activity remained positively correlated with $\mathrm{pH}$ two years after the application of the fertilizer to the soil. The observed increase in dehydrogenase and urease activity with increasing $\mathrm{pH}$ confirmed the stimulatory effect of $\mathrm{pH}$ on enzyme activity. Rusek (2006) found that dehydrogenase activity decreases with decreasing soil $\mathrm{pH}$. The composition of microbial communities depends on soil pH (Januszek et al., 2015; Lauber et al., 2008). According to Wolińska and Stępniewska (2012), pH affects soil enzyme activity by changing the ionic form of the active site of the enzyme as well as by affecting the substrate of the enzyme. Brzezińska et al. (2001) observed maximum 

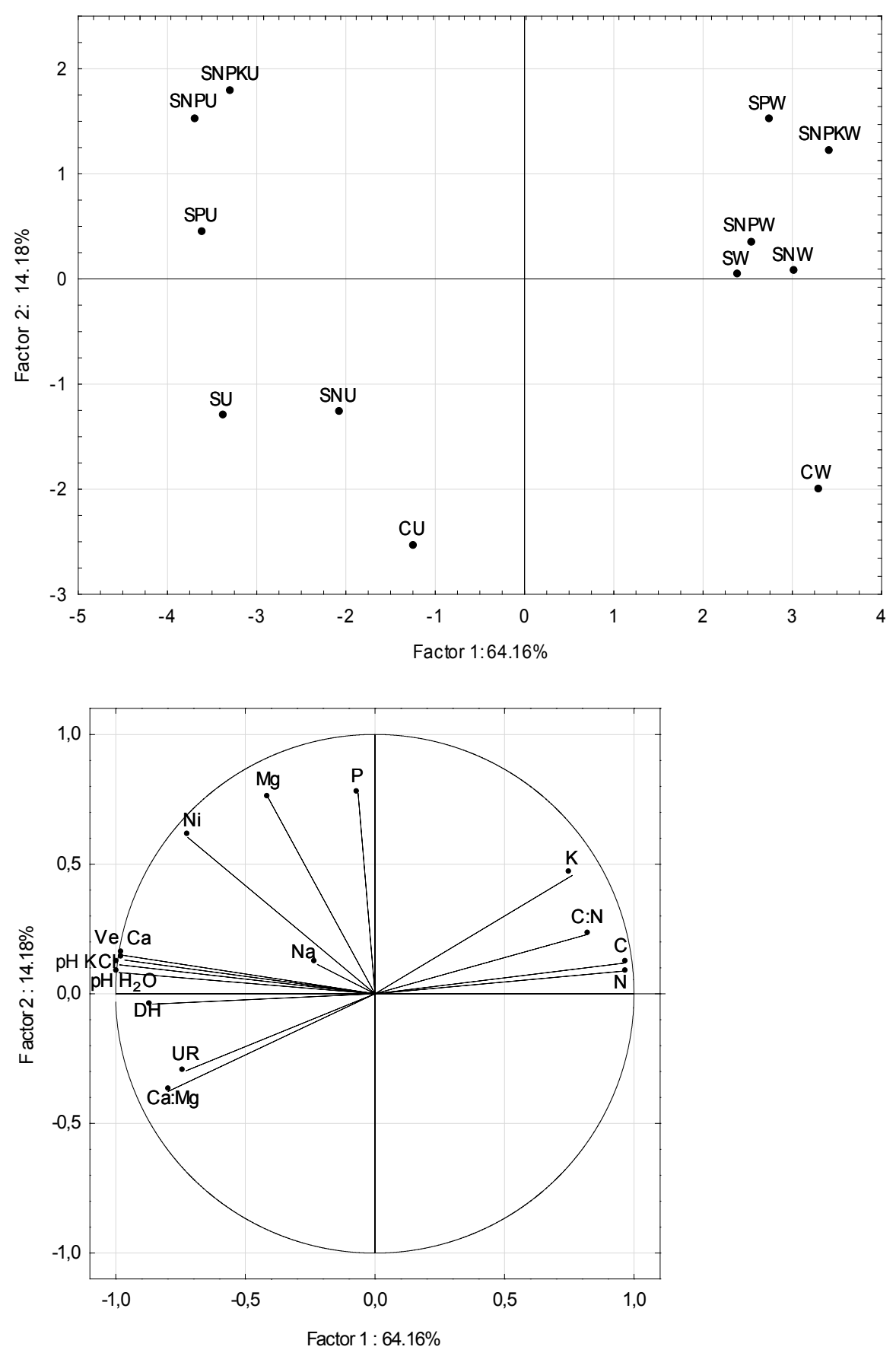

Fig. 1. Factorial plan and projection of variables on the factor-plane $1 \times 2$ (effect of fertilization in 2009, organic horizon); CU, SU, SNU, SPU, SNPU, SNPKU - variants of fertilization on the Ujsoły plots; CW, SW, SNW, SPW, SNPW, SNPKW - variants of fertilization on the Wisła plots.

dehydrogenase activity at a $\mathrm{pH}$ of 6.6 to 7.2 and found that organic matter was the most important factor significantly affecting the mobility of enzymes (Štursowá and Baldrian, 2011; Xiao-guang et al., 2011). In addition, Nazarkiewicz and Kaniuczak (2008) described a positive effect of the interaction between liming and mineral fertilization on the enzyme activity of dehydrogenase, phosphatase, and protease, including an increase in $\mathrm{pH}$.
The examined organic horizons exhibited the highest level of enzyme activity, which decreased with the depth of the studied soil profiles. The high activity of enzymes in the upper horizons of the soil is associated with the presence of microorganisms and their activity and the content of the organic matter constituting the feeding base. This pattern is linked mainly with the location of humus in the soil and the amount of available carbon substrates for the 

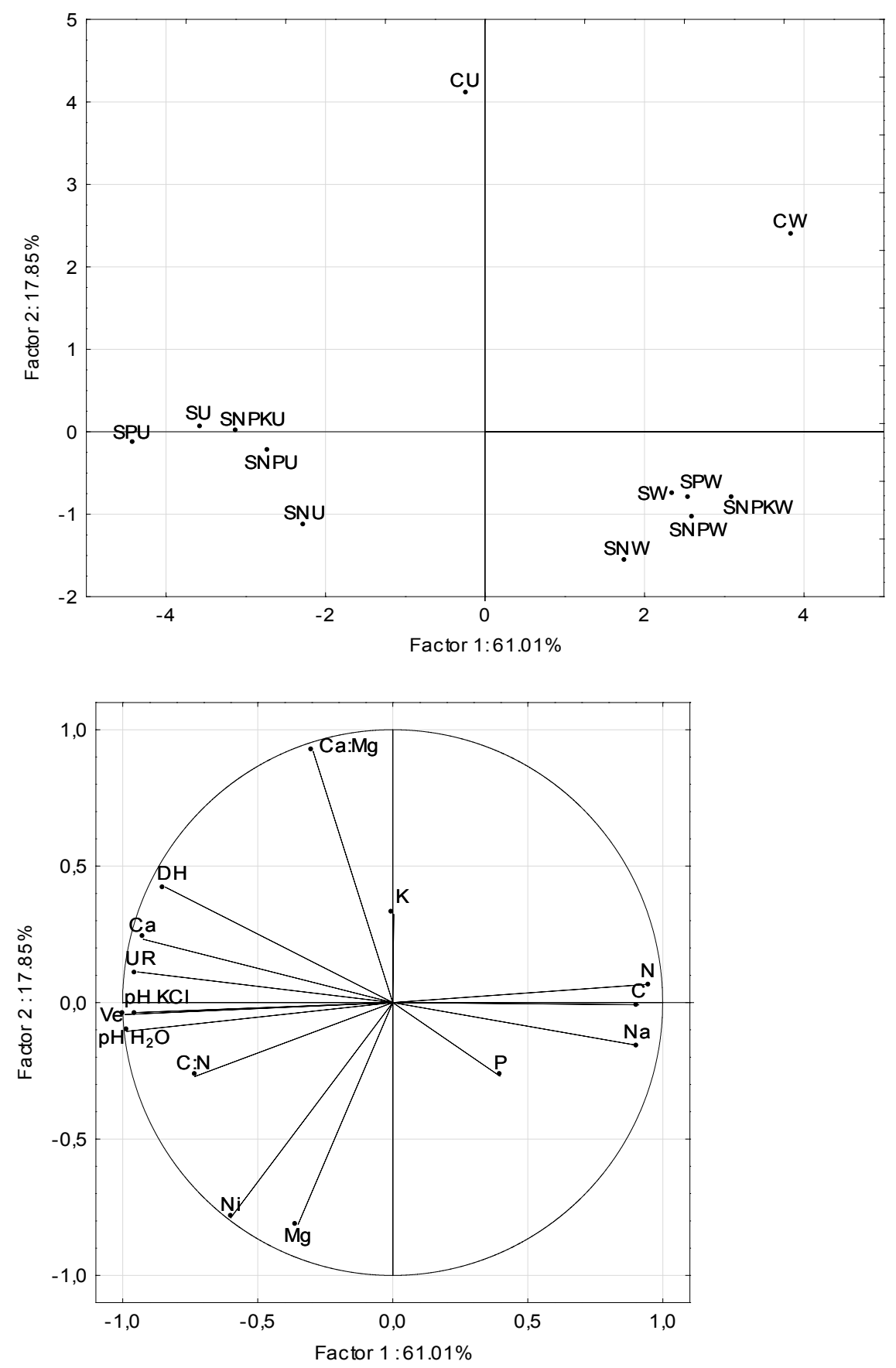

Fig. 2. Factorial plan and projection of variables on the factor-plane 1x2 (effect of fertilization in 2010, organic horizon). Explanations as in Fig. 1.

microorganisms present in the soil as well as the decreasing quantity of enzymes with the increasing depth of the soil profile. The observed decline in enzyme activity in the soil profile is fully consistent with the observations of Eivazi and Tabatabai (1990), Trasar-Cepeda et al. (1998), Kandeler et al. (1999), and Wang and Lu Qin (2006). Wolińska et al. (2015) as well as Veres et al. (2013) showed that soil enzyme activity acts as a 'sensor' of soil organic matter (SOM) decomposition. The SOM decomposition rate depends on substrate properties as well as availability of microorganisms and their enzymes.

Differences in enzyme activity may be related to the morphology of the studied soil profiles. The research plots at the Wisła and Ujsoły sites differ in the type of humus, which may produce a direct effect on enzyme activity. In the soil profile at the Wisła site, there is a larger organic 
T a b l e 4. Correlation between types of enzyme activity and soil characteristics

\begin{tabular}{cccc}
\hline Activity & $\mathrm{pH}_{\mathrm{H}_{2} \mathrm{O}}$ & $\mathrm{pH}_{\mathrm{KCl}}$ & $\mathrm{Ni}$ \\
\hline & & 2009 & \\
$\mathrm{DH}$ & 0.21 & 0.20 & $0.36^{*}$ \\
$\mathrm{UR}$ & 0.26 & 0.20 & 0.16 \\
& & 2010 & \\
$\mathrm{DH}$ & $0.65^{*}$ & $0.65^{*}$ & $0.35^{*}$ \\
$\mathrm{UR}$ & $0.78^{*}$ & $0.82^{*}$ & 0.09 \\
\hline
\end{tabular}

$\mathrm{DH}$ - dehydrogenase activity, UR - urease activity, ${ }^{*} \mathrm{p}<0.05$.

Ofh horizon, while the Oh horizon at the Ujsoły site is shallower. These horizons differ in the rate of decomposition of organic matter and in the rates of various biochemical processes. In addition, the thickness and the degree of decomposition of these horizons are determined by the temperature and moisture in the soil profile. According to Brzezińska et al. (2001), Brzostek and Finzi (2012), and Wallenstein et al. (2012), temperature and moisture are both important factors influencing enzyme activity in the soil. Adequately high levels of soil moisture determine the level of soil enzyme activity. According to Kubista (1982), the activity of dehydrogenase is closely related to the energy of the metabolism of microorganisms. Kubista (1982) suggests that microbial activity increases in the soil due to an increase in moisture. According to Brzezińska et al. (2001), an increase in water content in the soil significantly affects the level of activity of dehydrogenase. Steinweg et al. (2012) demonstrated that low soil moisture can strongly limit in-situ enzyme activity in soils.

Urease and dehydrogenase activities react well to the changes caused by fertilization. Mohammadi et al. (2012) suggested that urease activity could be used as an indicator of changes in the soil. In the organic and mineral horizons of the Wisła and Ujsoły research plots, urease activity decreased following fertilization. In addition, urease activity became reduced in the years that followed in the case of most fertilization treatments. According to Bhattacharya and Sahu (2013) as well as Liao and Raines (1984), urease activity in the soil may be inhibited by phosphorus fertilization. Hence, a reduction in the rate of the use of nitrogen obtained from urea may occur. Such a pattern was observed in this study in the second year following the fertilization in the A and AE horizons, where the fertilizer treatments with phosphorus inhibited the previously mentioned effect on urease activity. Many studies have shown that soil contamination with heavy metals may lead to a neative impact on ambient soil organisms and, consequently, on the biochemical activity of the soil (Friedlová, 2010; Kandeler et al., 1996). Bielińska (2006) found a negative correlation between the soil content of zinc, lead, and copper and the activity of enzymes - dehydrogenase, phosphatase, urease, and protease. High levels of heavy metal contamination $(\mathrm{Cd}$ and $\mathrm{Pb})$ reduce the number of soil microorganisms and affect nutrient cycling (Chen et al., 2005; Kucharski and Wyszkowska, 1998; Sardar et al., 2010). Dehydrogenase activity can be inhibited in the range from 10 to $90 \%$, which depends on the degree of soil contamination (Kucharski and Wyszkowska, 1998). According to the work by Wyszkowska et al. (2008), the activity of dehydrogenase and urease may decrease as a result of the introduction of nickel into the soil - already at a dosage of $100 \mathrm{mg} \mathrm{kg}^{-1}$. In this study, $6.69 \mathrm{~kg}$ of nickel were introduced into the soil with four tons per hectare introduced with serpentinite. However, stimulating effects of heavy metals have also been shown in the literature (Bååth, 1989). Metals detected in small amounts in the soil are not harmful and can even stimulate certain enzyme processes. It may be the case that a metal could be one of the components of the catalytic centre and may activate selected enzymes by creating a metal-substrate complex (Balicka and Varanka, 1978). No decrease in the level of urease activity following the fertilization with serpentinite in 2010 was observed and there was a lack of correlation with urease activity; the concentration of nickel in the soil did not inhibit the urease activity of the studied soils. Dehydrogenase activity in the studied $\mathrm{O}$ horizon increased within two years of the time of plot fertilization. This may suggest an increase in microbial activity after fertilization using all the treatments provided in the study and an absence of negative effects of the nickel used.

\section{CONCLUSIONS}

1. As a result of the use of the fertilizer (ground serpentinite, ground serpentinite $+\mathrm{N}$, ground serpentinite $+\mathrm{P}$, ground serpentinite $+\mathrm{NP}$, ground serpentinite $+\mathrm{NPK}$ ) the studied soils became significantly enriched in magnesium, and serpentinite contributed to the reduction in the molar ratio of exchangeable calcium to magnesium ions, which should facilitate the uptake of magnesium by the roots of trees due to the competition between calcium ions and magnesium ions. Lower doses of serpentinite $(<4000 \mathrm{~kg}$ $\left.\mathrm{ha}^{-1}\right)$ should be used to fertilize light soils with a magnesium deficiency and weakened tree stands. Higher doses of serpentinite increase the level of acidification of the upper mineral horizons.

2. An increase in the supply of phosphorus was observed after the fertilization of all the soil horizons of both experimental plots with superphosphate.

3. Fertilization of the soil using serpentinite in combination with nitrogen, phosphorus, and potassium fertilizer stimulates the activity of dehydrogenase in soil under spruce stands.

4. The positive impact of soil fertilization on dehydrogenase activity is reflected in the organic horizon. Reduced activity of urease was noted in the studied organic horizon fertilized in combination with phosphorus in the years after 
the fertilization period, which confirmed that it can reduce urease activity and contribute to inhibition of nitrification in this way.

5. The absence of a negative impact of the serpentinite fertilizer used in the study on the enzyme activity of the studied soils under spruce stands suggests an absence of toxic concentrations of heavy metals in the soil, and further suggests the feasibility of using this type of fertilizer in forestry.

Conflict of interest: The Authors do not declare conflict of interest.

\section{REFERENCES}

Acosta-Martínez V., Cruz L., Sotomayor-Ramírez D., and Pérez-Alegría L., 2007. Enzyme activities as affected by soil properties and land use in tropical watershed. Appl. Soil Ecol., 35(1), 35-45.

Ajwa H.A., Dell C.J., and Rice C.W., 1999. Changes in enzyme activities and microbial biomass of tallgrass prairie soil as related to burning and nitrogen fertilization. Soil Biol. Biochem., 31, 769-777.

Alef K. and Nannipieri P., 1995. Enzyme activities. In: Methods in Applied Soil Microbiology and Biochemistry (Eds K. Alef, P. Nannipieri), Academic Press, London, New York, San Francisco.

Balicka N. and Varanka M.W., 1978. Effect of industrial pollution of air on soil microflora. Zesz. Probl. Post. Nauk Roln., 206, 17-27.

Bååth E., 1989. Effect of heavy metals in soil on microbial processes and populations (a review). Water Air Soil Pollut., 47, 335-379.

Bhattacharya A. and Sahu S.K., 2013. A comparative study of the effect of imdacloprid and dimethoate on soil enzyme. Int. J. Biosci., 3(1), 172-182.

Bielińska E.J., 2006. Ecological characteristics of soils in urban allotments. J. Res. Appl. Agric. Engng., 5(2), 13-16.

Błońska E., Małek S., Januszek K., Barszcz J., and Wanic T., 2015. Changes in forest soil properties and in spruce stands after dolomite, magnesite and serpentinite fertilization. European J. Forest Res., 134, 981-990.

Brzezińska M., Stępniewska Z., Stępniewski W., Włodarczyk T., Przywara G., and Bennicelli R., 2001. Effect of oxygen deficiency on soil dehydrogenase activity (pot experiment with barley). Int. Agrophysics, 15(1), 3-7.

Brzostek E.R. and Finzi A.C., 2012. Seasonal variation in the temperature sensitivity of proteolytic enzyme activity in temperate forest soils. J. Geophysic Res., 117, G01018.

Cakmak J. and Yazici A.M., 2010. Magnesium: a forgotten element in crop production. Better Crops, 94, 23-25.

Carter M.R. and Gregorich E.G., 2006. Soil sampling and methods of analysis. New York, USA, CRC Press.

Chen C.L., Lio M., and Huang CY., 2005. Effect of combined pollution by heavy metals on soil enzymatic activities in areas polluted by tailings from $\mathrm{Pb}-\mathrm{Zn}-\mathrm{Ag}$ mine. J. Environ., Sci., 17, 637-640.

Eivazi F. and Tabatabai M.A., 1990. Factors affecting glucosidase and. galactosidase activity in soils. Soil Biol. Biochem., 22, 891-897.
Friedlová M., 2010. The influence of heavy metals on soil biological and chemical properties. Soil Water Res., 5(1), 21-27.

Gianfreda L. and Ruggiero P., 2006. Enzyme activities in soil. In: Nucleic acids and proteins in soil (Eds P. Nannipieri, K. Smalla), Springer, Berlin, 8, 257-311.

Gil-Sotres F., Trasar-Cepeda C., Leiros M.C., and Seoane S., 2005. Different approaches to evaluating soil quality using biochemical properties. Soil Biol. Biochem., 37, 877-887.

Gorlach E. and Gorlach K., 1983. Comparison of the effect of $\mathrm{CaCO}_{3}$ and $\mathrm{MgCO}_{3}$ as well as calcium-magnesium fertilization on the growth and the chemical composition of some plant species. Part I. The yield of dry mass and the content of some macroelements (in Polish). Soil Sci. Annual., 34(4), 29-43.

Gransee A. and Führs H., 2013. Magnesium mobility in soils as a challenge for soil and plant analysis, magnesium fertilization and root uptake under adverse growth conditions. Plant Soil, 368(1), 5-21.

Huber C., Baier R., Göttlein A., and Weis W., 2006. Changes in soil, seepage water and needle chemistry between 1984 and 2004 after liming an N-saturated Norway spruce stand at the Höglwald, Germany. Forest Ecol. Manag., 233, 11-20.

Jandl R., Glatzel G., Katzensteiner K., and Eckmüllner O., 2001. Amelioration of magnesium deficiency in a Norway spruce stand (Picea abies) with calcined magnesite. Water Air Soil Pollut., 125, 1-17.

Januszek K., 2006. Concentration of macronutrients and selected microelements in the needles of weakened and not weakened spruce stands on the Lądek Zdrój Forest District area in the Śnieżnik Massif and fertilization recomendations. Research report ordered by RDLP Wrocław. Forest Soil Science Department, University of Agriculture in Kraków, Poland.

Januszek K., Błońska E., Długa J., and Socha J., 2015. Dehydrogenase activity of forest soils depends on the used assay Int. Agrophys., 29(1), 47-59.

Januszek K., Błońska E., Wanic T., Dawid A., and Warchol M., 2011. Selected properties of soils of spruce stands in the Western Beskid Mts. one year after fertilization with dolomite, magnesite and serpentinite (in Polish). Soil Sci. Annual, 62(1), 1-12.

Kandeler E., Kampichler C., and Horak O., 1996. Influence of heavy metals on the functional diversity of soil communities. Biol. Fertil. Soils, 23, 299-306.

Kandeler E., Tscherko D., and Spiegel H., 1999. Long-term monitoring of microbial biomass, $\mathrm{N}$ mineralisation and enzyme activities of a Chernozem under different tillage management. Biol. Fertil. Soils, 28, 343-351.

Kreutzer K., 1995. Effects of forest liming on soil processes. Plant Soil, 168-169, 447-470.

Kubista K., 1982. Dehydrogenase activity in soil and its dependence on watering system. PTG PKN, Soil Biology Committee, III, 27, 89-93.

Kucharski J. and Wyszkowska J., 1998. The effect of copper on biological properties of soil. In: Ecological aspects of soil microbiology (Eds A. Sawicka, G. Durska). AR Poznań, 173-178.

Landmann G., Hunter I.R., and Hendershot R., 1997. Temporal and spatial development of magnesium deficiency in forest stands in Europe, North America and New Zeland. In: Magnesium Deficiency in Forest Ecosystems (Eds R.F. Hüttl, W. Schaaf). Kluwer Academic Publishers, 23-64. 
Lauber C.L., Strickland M.S., Bradford M.A., and Fierer N., 2008. The influence of soil properties on the structure of bacterial and fungal communities across land-use types. Soil Biol. Biochem., 40, 2407-2415.

Liao C.F.H. and Raines S.G., 1985. Inhibition of soil urease activity by amido derivatives of phosphoric and thiophosphoric acids. Plant Soil, 85, 149-152.

Liu J.X., 2004. Correlative research on the activity of enzyme and soil nutrient in the different types of farmland. Chin. J. Soil Sci., 35(4), 20-23.

Lundström U.S., Bain D.C., Taylor A.F.S., and Van Hees P.A.W., 2003. Effects of acidification and its mitigation with lime and wood ash on forest soil processes: a review. Water Air Soil Pollut., 3, 5-28.

Małek S., 2010. Nutrient fluxes in planted Norway Spruce stands of different age in Southern Poland. Water Air Soil Pollut., 209, 45-59.

Małek S., Barszcz J., and Majsterkiewicz K., 2012. Changes in the threat of spruce stand disintegration in the Beskid Śląski and Żywiecki Mts in the years 2007-2010. J. Forest Sci., 58(12), 519-529.

Małek S., Januszek K., Barszez J., Błońska E., Wanic T., Gąsienica-Fronek W., and Kroczek M., 2011. Preliminary assessment of the ecochemical condition of soils after fertilization of younger spruce Picea abies (L.) H. Karst. stands in the Beskid Śląski and Żywiecki Mts. Folia Forestalia Polonica, A, 53(2), 93-104.

Melero S., Ruiz Porras J.C., Herencia J.F., and Madejón E., 2006. Chemical and biochemical properties in a silty loam soil under conventional and organic management. Soil Till. Res., 90, 162-170.

Mijangos I., Pérez R., Albizu I., and Garbisu C., 2006. Effects of fertilization and tillage on soil biological paramters. Enzyme Microb. Tech., 40, 100-106.

Mohammadi K., Heidari G., Nezhad M.T.K., Ghmari S., and Sohrabi Y., 2012. Contrasting soil microbial responses to fertilization and tillage systems in canola rhisosphere. Saudia J. Biol. Sci., 19, 377-383.

Nannipieri P., Giagnoni L., Renella G., Puglisi E., Ceccanti B., Masciandaro G., Fornasier F., Moscatelli M.C., and Marinari S., 2012. Soil enzymology: classical and molecular approaches. Biol. Fertil. Soil, 48, 743-762.

Nazarkiewicz M. and Kaniuczak J., 2008. Effect of liming and mineral fertilization on the enzymatic activity of greybrown podzolic soils formed from loess. Polish J. Soil Sci., 41(2), 201-207.

Ostrowska A., Gawliński S., and Szczubiałka Z., 1991. Methods of analysis and assessment of soil and plant properties (in Polish). Environmental Protection Institute, Warszawa, 1-334.

Rusek A., 2006. Dehydrogenase activity in soils polluted by diesel oil in a field lysimeter experiment. Soil Sci. Annual, 57, 106-116.

Sardar K., Abol El-Latif H., Min Q., Shafigur R., and Ji-zheng H., 2010. Effect of $\mathrm{Cd}$ and $\mathrm{Pb}$ on soil microbial community structure and activities. Environ. Sci. Poll. Res., 17, 288-296.

Steinweg J.M., Dukes J.S., and Wallenstein M.D., 2012. Modeling the effects of temperature and moisture on soil enzyme activity: linking laboratory assays to continuous field data. Soil Biol. Biochem., 55, 85-92.
Šrámek V., Sitková Z., Małek S., Pavlenda P., and Hlásny T., 2010. Air pollution and forest nutrition - what are their roles in spruce forest decline? In: Spruce forest decline in the Beskids (Eds T. Hlásny, Z. Sitková), National Forest Centre - Forest Research Institute Zvolen \& Czech University of Life Sciences Prague \& Forestry and Game Management Research Institute Jílovíště - Strandy., Zvolen, 49-67. ISBN 978-80-8093-127-8.

Štursowá M. and Baldrian P., 2010. Effects of soil properties and management on the activity of soil organic matter transforming enzymes and the quantification of soil-bound and free activity. Plant Soil, 338, 99-110.

Tabatabai M.A. and Bremner J.M., 1972. Assay of urease activity in soils. Soil Biology Biochemistry, 4, 479-487.

Tabatabai M.A. and Dick W.A., 2002. Enzymes in soil: Research and developments in measuring activities. In: Enzymes in the Environment (Eds R.G. Burns, R.P. Dick). Marcel Dekker, New York, USA.

Trasar-Cepeda C., Leiro's M.C., Gil-Sotres F., and Seoane S., 1998. Towards a biochemical quality index for soils: an expression relating several biological and biochemical properties. Biol. Fertil. Soils, 26, 100-106.

Trasar-Cepeda C., Leiro's M.C., Seoane S., and Gil-Sotres F., 2000. Limitations of soil enzymes as indicators of soil pollution. Soil Biol. Biochem., 32, 1867-1875.

Veres Z., Kotroczó Z., Magyaros K., Tóth J.A., and Tóthmérész B., 2013. Dehydrogenase activity in a litter manipulation experiment in temperate forest soil. Acta Silvatica and Lignaria Hungarica, 9, 25-33.

Wallenstein M.D., Haddix M.L., Lee D.D., Conant R.T., and Paul E.A., 2012. A litter-slurry technique elucidates the key role of enzyme production and microbial dynamics in temperature sensitivity of organic matter decomposition. Soil Biol Biochem., 47, 18-26.

Wang X.C. and Lu Q., 2006. Beta-glucosidase activity in paddy soils of the Taihu Lake region, China. Pedosphere, 16(1), 118-124.

Wolińska A. and Stępniewska Z., 2012. Dehydrogenase activity in the soil environment. In: Dehydrogenases (Ed. R.A. Canuto). In Tech, DOI: 10.5772/48294.

Wolińska A., Stępniewska Z., and Pytlak A., 2015. The effect of environmental factors on total soil DNA content and dehydrogenase activity. Archives Biological Sci., 67 (2), 493-501.

Wyszkowska J., Boros E., and Kucharski J., 2008. Enzymatic activity of nickel-contaminated soil. J. Elementol., 13(1), 139-151.

Xiao-guang J., Chong-sheng G., Guo-hong L., and Yu-yu S., 2011. Effect of long-term fertilization on soil enzyme activities under different hydrothermal conditions in northeast China. Agric. Sci. China, 10(3), 412-422.

Yang L., Li T., Li F., Lemcoff J.H., and Cohen S., 2008. Fertilization regulates soil enzymatic activity and fertility dynamics in a cucumber field. Scientia Horticulturae, 116, 21-26.

Yao H., Bowman D., Ruftyy T., and Shi W., 2009. Interactions between $\mathrm{N}$ fertilization, grass clipping addition and $\mathrm{pH}$ in turf ecosystems: Implications for soil enzyme activities and organic matter decomposition. Soil Biol. Biochem., 41, 1425-1432.

Zhang L., Chen W., Burger M., Yang L., Gong P., and Wu Z., 2015. Changes in soil carbon and enzyme activity as a result of different long-term fertilization regimes in a greenhouse field. PLiS ONE 10(2): e0118371. 